Arab Univ. J. Agric. Sci., Ain Shams Univ., Cairo, Egypt

28(4), 1187-1202, 2020

Website: http://ajs.journals.ekb.eg

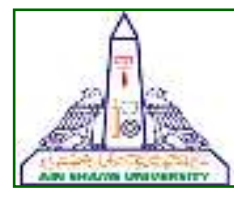

1187

\title{
Impact of Nanoparticles of In Vitro Propagation of Date Palm cv. Barhee by Immature Inflorescences
}

Fared M Rohim ${ }^{1 *}$, El-Wakeel H ${ }^{2}$, Abd El-Hamid A ${ }^{2}$, Eman A Abd El-Moniem ${ }^{1}$

1- Horticultural Crops Technology, National Research Centre, P.O. Box 12622 Dokki, Giza, Egypt

2- Horticulture Dept, Fac of Agric, Ain Shams Univ, P.O. Box 68, Hadayek Shoubra 11241, Cairo, Egypt

${ }^{*}$ Corresponding author: fm.rahim@nrc.sci.eg

Received 29 August, 2020

Accepted 1 November, 2020

\begin{abstract}
The impact of nano silver \& nano chitosan particles on sterilization, nano $\mathrm{Fe}$ and $\mathrm{Zn}$ on callus formation of immature inflorescence of date palm cv. Barhee during the establishment stage was investigated with immersion and adding to MS culture medium. The lowest total contamination percentage and the highest survival percentage were achieved with nano silver particles at200 $\mathrm{mg} / \mathrm{l}$, and nano chitosan at 150, and $200 \mathrm{mg} / \mathrm{l}$. The lowest contamination \%recorded in medium culture containing silver nanoparticles at $4 \mathrm{mg} / \mathrm{l}$ with NAA at $100 \mathrm{mg} / \mathrm{l}$ and chitosan nanoparticles at $4 \mathrm{mg} / \mathrm{l}$ with 2,4-D at $100 \mathrm{mg} / \mathrm{l}$ The optimum callus formation percentage and callus size were obtained on MS medium supplemented with picloram at $8 \mathrm{mg} / \mathrm{l}$. The highest callus weight and size were showed with NAA at $10 \mathrm{mg} / \mathrm{l}$, 2ip at $6 \mathrm{mg} / \mathrm{l} \& \mathrm{Kin}$ at $6 \mathrm{mg} / \mathrm{l}$ during callus proliferation. In multiplication stage, the highest number of shoot / culture were occurred on MS medium culture supplemented with Fe nano particles at $20.8 \mathrm{mg} / \mathrm{l}$, MS medium culture supplemented by Fe nano particles at $27.8 \mathrm{mg} / \mathrm{l}$ and $\mathrm{Zn}$ nano particles at $4.3 \mathrm{mg} / \mathrm{l}$ in the first subculture without any significant differences among them. The highest average shoo length $(\mathrm{cm})$ was obtained with MS medium containing Fe nano particles at $27.8 \mathrm{mg} / \mathrm{l}$, MS medium supplemented by Fe nano particles at $20.8 \mathrm{mg} / \mathrm{l}$ and $\mathrm{Zn}$ nano particles at $4.3 \mathrm{mg} / \mathrm{l}$ in the first subculture without any significantly differences among them. Interaction between cytokinins and auxin concentration, indicated, the highest number of shoots / culture were achieved with NAA at $2.0 \mathrm{mg} / \mathrm{l}$, 2ip at $4 \mathrm{mg} / \mathrm{l}$, kin at $4 \mathrm{mg} / \mathrm{l}$ during the $1^{\text {st }}, 2^{\text {nd }} \& 3^{\text {rd }}$ subcultures, respectively. The highest rooting percentage and
\end{abstract}

number of roots/ microshoots were obtained with MS containing NAA at $0.5 \mathrm{mg} / \mathrm{l}$. The highest survival percentages in acclimatization stage were occurred with medium mixtures of sand: peat: vermiculite: perlite at $(1: 2: 1: 1)$ and $(2: 1: 1: 1)$, respectively.

Keywords: Date palm, Immature Inflorescence, In Vitro, Propagation, Nanoparticles, Acclimatization

Abbreviation: NAA: $\alpha-N a p h t h a l e n e$ acetic acid, IBA: Indole-3-butyric acid, 2ip: N6-(2-isopentyl) adenine, Kin: 6- furfurylaminopurine. TDZ: Thidiazuron N-phenyl-N'- 1,2,3-thiadiazol- 5-ylurea, BAP: Benzyl amino Purine, NOA: Napthoxy acetic acid, TiO: titanium Oxide, PVP: Polyvinylpyrrolidone, NS: nano silver particles, $\mathrm{N}$ chito: nano chitosan particles.

\section{Introduction}

Date palm (Phoenix dactylifera L.) is one the most important fruit crops of the world in arid region, a diploid with $2 \mathrm{n}=36$, is a member of the monocotyledon's family Arecacea classified as a dioecious tall evergreen. In Egypt harvested area of date palm about 122371.59 fedan and produce about 1590414 tonnes (FAO 2019).

Micropropagation has great potential for the multiplication of female and male date palms of commercially grown cultivars by using inflorescences. This approach is simple, convenient, and much faster than the conventional method of using shoot-tip explants. The potential of inflorescence explants have been verified to develop direct and indirect of somatic embryos formation and organogenesis. 
Inflorescence explants had proved useful in avoiding many obstacles that face shoot-tip explants, such as high percentage of contamination, browning, and long initiation stage (Mohan et al 2011). Inflorescence-based micropropagation gave great potential for the propagation of individual recalcitrant female and male date palms and cultivars of commercial interest and is particularly useful when offshoot availability is limited. This type of propagation can be skillful in a short time with minimal effort compared with the traditional practice of using shoot-tip explants (Mohan et al 2011).

The term nanosilver indicate nanoparticles of silver ranging in size between $1 \mathrm{~nm} \& 100 \mathrm{~nm}$. Thus a single silver atom $(\mathrm{Ag})$ or silver ion $(\mathrm{Ag}+)$ is not nanomaterial. A particle of nanosilver may or may not be charged on its surface or generate silver ions. Such sa ionic silver, nanosilver particles are very potent killer of bacteria, fungi, algae, and some viruses, including HIV (Becker et al 2000). Newly, nanosilver have been showed at concentrations as low as $0.14 \mu \mathrm{g} / \mathrm{ml}$ to be toxic to several species of nitrifying bacteria (Reidy et al 2013). In date palm. The optimal concentrations for successful inflorescence growth was 5 or $10 \mathrm{mg} /$ I Picloram and through studying the residuals effect of Picloram on inflorescences proliferation in the presence of three concentrations of TDZ, it found, TDZ at $0.5 \mathrm{mg} / \mathrm{l} \mathrm{com-}$ bined with NAA at $0.1 \mathrm{mg} / \mathrm{l}$ was more effective to induce direct somatic embryos and gave the highest inflorescence proliferation percentage, while the high level of Picloram induced callus (Sidky 2014).

\section{Materials and Methods}

This study was achieved through three successive years of 2015 to 2018 in the tissue culture technique laboratory, Central Laboratories Network, National Research Center, Dokki, Egypt. This investigation was performed throughout four stages:

\subsection{Plant materials and explant types}

The inflorescences are collected from 10-yearold trees planted in the Giza area during the flowering season, from February to March from the mother tree. The spathe dimensions are variable, measuring $15-25 \mathrm{~cm}$.

\subsection{Sterilization procedure experiment}

All of plant material disinfection were done in several steps; first, the spathe was immersed for 10 minutes in a solution fungicide containing $3 \mathrm{~g} / \mathrm{l}$ of Topsin, then, soaked in clorox solutions at $30 \% \mathrm{v} / \mathrm{v}$ commercial bleach (sodium hypochlorite percent at $5.25 \%$ ) containing two drops of Tween 20 per 100 $\mathrm{ml}$ solution for 25 minutes and then soaked for 5 minutes in mercuric chloride at $200 \mathrm{mg} / \mathrm{l}$ (as a control treatment), then soaked for 1 minut in ethyl alcohol solution at $70 \%$. The spathes were opened under aseptic conditions and the spikelets were washed three times carefully with sterile distilled water and cut into a small pieces (1-2 cm) and kept into an antioxidant solution (ascorbic acid $100 \mathrm{mg} / \mathrm{l}$, citric acid $150 \mathrm{mg} / \mathrm{l}$ ) to protect the plant material from browning.

Some the Spikelet species with (2-3) florets were immersed for $7 \mathrm{~min}$ in nano particles materials solutions as follows:

1- Silver nano particles solutions at $50 \mathrm{mg} / \mathrm{l}$.

2- Silver nano particles solutions at $100 \mathrm{mg} / \mathrm{l}$.

3- Silver nano particles solutions at $200 \mathrm{mg} / \mathrm{l}$

4- Chitosan nano particles solutions at $50 \mathrm{mg} / \mathrm{l}$.

5- Chitosan nano particles solutions at $100 \mathrm{mg} / \mathrm{l}$.

6- Chitosan nano particles solutions at $150 \mathrm{mg} / \mathrm{l}$.

7- Chitosan nano particles solutions at $200 \mathrm{mg} / \mathrm{l}$.

8- Compare with commercial bleach clorox at $30 \%$ with ethanol at $70 \%$.

9- Commercial bleach with mercuric chloride $(\mathrm{Hg}$ $\mathrm{Cl}$ ) at $200 \mathrm{mg} / \mathrm{l}$.

The nano particles materials were obtained from a private company that was equipped for this study. Spikelet fragments with at least 2 or 3 florets were cultured on MS medium full strength to indice callus formation. Experiments were designed in a completely randomized design. Nine treatments $\times$ three replicates $\times 3$ jars. After one month, contamination percentage, browning degree and survival percentage were recorded.

In this investigation we study the activity antimicrobial of nano silver and nano chitosan. The ability of nano silver and nano chitosan after confirm to reduce the microorganism, we decide to using and adding NS and chitosan to tissue culture media can reduce and remove microorganisms in MS media and then the explants can growth very well and we try effort to establish an in vitro propagation protocol of date palm cv. Barhee by immature inflorescences. 

by immature inflorescences

\subsection{Culture media and incubation condition}

MS media (Murashige and Skoog 1962) salts at full strength were supplemented with vitamins, Inositol at $100 \mathrm{mg} / \mathrm{l}$, glutamine at $200 \mathrm{mg} / \mathrm{l}$, adenine at $100 \mathrm{mg} / \mathrm{l}$, citric acid at $150 \mathrm{mg} / \mathrm{l}$, ascorbic acid at 150 $\mathrm{mg} / \mathrm{l}$ during establishment stage, callus formation and shoot multiplication stage. Sucrose at $30 \mathrm{~g} / \mathrm{l}$, and activated charcol at $1 \mathrm{~g} / \mathrm{l}$ were used and all types of solid media which used in this study were solidified with purified agar-agar at $7 \mathrm{~g} / \mathrm{L}$. The $\mathrm{pH}$ was adjusted to $5.7 \pm 0.02$ by $\mathrm{NaOH}$ and $\mathrm{HCl}$. The media were autoclaved at $100 \mathrm{~K}$. pa (15 P.S.I) and $121^{\circ} \mathrm{C}$ for twenty minutes, then the media lefted to cool and harden for 24 hours before being used.

\subsection{Establishment stage}

2.4.1 Effect of auxin type, concentration, silver, and chitosan nanoparticles concentration added to MS medium on contamination \%, browning degree and survival percentage of date palm cv. Barhee immature inflorescences

MS medium containing auxin 2,4-D at $(5,10,50$ and $100 \mathrm{mg} / \mathrm{l})$, NAA at $(5,10,50$ and $100 \mathrm{mg} / \mathrm{l}$, silver nanoparticles at $(1,2,3$ and $4 \mathrm{mg} / \mathrm{l})$ and chitosan nanoparticles at $(1,2,3$ and $4 \mathrm{mg} / \mathrm{l})$ were added to MS culture medium supplemented with cytokinins (2ip at $3 \mathrm{mg} / \mathrm{l} \& \mathrm{kin}$ at $3 \mathrm{mg} / \mathrm{l}$ ) during establishment stage. Cultures were incubated in darkness and room temperature was maintained at $25 \pm 2^{\circ} \mathrm{C}$ during establishment stage. During the first three months of incubation, cultures were incubated under complete darkness to inhibt polyphenol oxidation which is activited under light conditions. Total contamination (fungal \% and bacterial \%), browning degree and survival percentage were recorded after 6 weeks under dark incubation.

This experiment contained 2 auxin types $\times 4$ concentration of auxin each with of one +2 nanoparticles material $\times 4$ concentration+ MS free hormones without nanoparticles $=17$ treatments. Experiment was designed in a completely randomized design. The degree of browning was evaluated visually as scores (index values), using the method described by Pottino (1981). Negative browning $=1$ Small browning $=2$ Medium browning $=3$ Large browning $=4$.
2.4.2 Effect of auxin type, concentration added to MS medium on callus formation and callus size of date palm cv. Barhee immature inflorescences during initiation stage

Callus about $3 \mathrm{~g}$ were transferred to MS medium salts at full strength contained sucrose at $30 \mathrm{~g} / \mathrm{l}$, and activated charcol at $1 \mathrm{~g} / \mathrm{l}$, supplemented with Picloram at $(2,4,6$, and $8 \mathrm{mg} / \mathrm{l}), 2,4-\mathrm{D}$ at $(4,10,15$ and 25 $\mathrm{mg} / \mathrm{l})$ and NAA at $(4,10$ and $20 \mathrm{mg} / \mathrm{l})$ with cytokinins (2ip at $6 \mathrm{mg} / \mathrm{l}+\mathrm{Kin}$ at $6 \mathrm{mg} / \mathrm{l}$ ) to improve callus formation. Cultures were incubated in complete darkness and room temperature was maintained at $25 \pm$ $2{ }^{\circ} \mathrm{C}$ to improve callus formation and avoid polyphenol oxidation which is catalyzed under light conditions. Callus formation percentage and callus size were recorded after 12 weeks of cultivation. The degree of callus formation and callus size were evaluated visually as scores (index values), using the method described by Pottino (1981).

This experiment contained 2 auxin types $\times 4$ concentration+ other one type $(\mathrm{NAA}) \times 3$ concentration supplemented cytokinin type with 1 concentration $=11$ treatments. Experiment was coordinated in a completely randomized design. Each treatment contained 3 replicates and each replicate contained 3 jars, each jars include one cluster.

2.4.3 Effect of auxin type and concentration on callus formation percentage, callus size and browning degree of date palm cv. Barhee immature inflorescences during callus proliferation stage

Callus about $3 \mathrm{~g}$ were transferred to MS medium salts at full strength contained sucrose at $30 \mathrm{~g} / \mathrm{l}$, and activated charcol at $1 \mathrm{~g} / \mathrm{l}, \mathrm{NAA}$ at $(5,10$ and $20 \mathrm{mg} / \mathrm{l})$, 2 ip at ( 3 and $6 \mathrm{mg} / \mathrm{l}) \& \mathrm{Kin}$ at ( $0,3 \& 6 \mathrm{mg} / \mathrm{l})$. Callus weight, callus size and browning degree were recorded during callus proliferation after three months. Callus subculture was carried out every six weeks.

This experiment contained 1 auxin types $\times 3$ concentration +2 cytokinin type $\times 3$ concentration $=$ 9 treatments. Experiment was harmonious in a completely randomized design. Every treatment contained 3 replicates and each replicate contained 3 jars, each jars include $3 g$ callus. The degree of callus formation and browning degree were rated visually as scores, using the method qualified by Pottino (1981). Small callus $=1$ Medium callus $=2$ Large callus $=3$ Extra-large callus $=4$. 


\subsection{Multiplication stage}

2.5.1 Effect of Fe and Zn nanoparticles concentration added to MS culture medium on number of shoots/culture and average shoot length $(\mathrm{cm})$ of date palm cv. Barhee callus culture during shoot formation stage

Microshoots about $(2-3 \mathrm{~cm})$ were cultured on MS medium salts at full strength used supplemented with vitamins, Ino-sitol at $100 \mathrm{mg} / \mathrm{l}$, glutamine at 200 $\mathrm{mg} / \mathrm{l}$, adenine at $100 \mathrm{mg} / \mathrm{l}$, citric acid at $150 \mathrm{mg} / \mathrm{l}$, a scorbic acid at $150 \mathrm{mg} / \mathrm{l}$, sucrose at $30 \mathrm{~g} / \mathrm{l}$, and PVPat $2 \mathrm{~g} / \mathrm{l}$, nano particles were tested for culture media in the stage of shoot multiplication with MS medium, Fe nanoparticles $(1 \mathrm{x}=27.8,3 / 4=20.85,1 / 2=$ $13.9, \& 1 / 4=6.95 \mathrm{mg} / \mathrm{l})$ and $\mathrm{Zn}$ nanoparticles $(1 \mathrm{x}=8.6$, $3 / 4=6.45,1 / 2=4.3 \& 1 / 4=2.15 \mathrm{mg} / \mathrm{l})$.

This experiment contained 2 nanoparticles types $\times 4$ concentration + MS medium macro and micro elements $=9$ treatments. Experiment was coordinated in a completely randomized design. Every one treatment contained 3 replicates and each replicate contained 3 jars, every one jar include one shoot.

2.5.2 Effect of auxin and cytokinins concentration on number of shoot / culture and average shoot length $(\mathrm{cm})$ of date palm Barhee callus culture during shoot multiplication stage

NAA $(0,0.5,1,2 \& 4 \mathrm{mg} / \mathrm{l}), 2 i p$ and kin at $(0,0.5$, $1,2 \& 4 \mathrm{mg} / \mathrm{l})$ also were tested. MS medium containing $\mathrm{Fe} \mathrm{SO} 4.7 \mathrm{H} 2 \mathrm{O}$ at $27.8 \mathrm{mg} / \mathrm{l}$ and $\mathrm{Zn} \mathrm{SO} 4$ at 8.6 $\mathrm{mg} / \mathrm{l}$ were used a control treatment. Shoot cultures were incubated under culture room $26 \pm 2^{\circ} \mathrm{C}$ and day-light condition16 hour for three re-cultures. Numbers of shoots and average shoot length $(\mathrm{cm})$ /culture were listed every six weeks for three subcultures. This experiment contained 1 auxin type's $\times 5$ concentration storage there experiment in 2 cytokinin type $\times 5$ concentrations through three subculture. Experiment was harmonious in a factorial completely randomized design. Every one treatment contained 3 replicates and each replicate contained 3 jars, each jars include one shoots.

\subsection{Rooting Stage}

2.6.1 Effect of auxin type \& concentration on rooting percentage, number of roots and root length $(\mathrm{cm})$ of date palm cv. Barhee microshoots during rooting stage

Microshoots of date palm about 5-7 cm length produced after the $3^{\text {th }}$ subculture were transferred to MS rooting medium at $1 / 2$ strength supplemented with NAA at $0.2,0.5 \& 1.0 \mathrm{mg} / \mathrm{l}$ or IBA at 1.0, 2.0, \& $3.0 \mathrm{mg} / \mathrm{l}$. Rooting percentage, number of roots $/ \mathrm{mi}-$ croshoots \& average root length $(\mathrm{cm})$ were on record after six weeks on rooting medium.

This experiment contained 2 auxin types $\times 3$ concentration $=6$ treatments. Experiment was coordinated in a completely randomized design. Every one treatment contained 3 replicates and each replicate contained 3 jars, each jar include one microshoot.

\subsection{Acclimatization stage}

2.7.1 Effect of medium mixtures on survival \% of date palm cv. Barhee plantlet during acclimatization stage

Plantlets of date palm cv. Barhee about 10-12 $\mathrm{cm}$ in length and have a more developed root system were rinsed carefully with water distilled and sterile to remove adhering medium and transplanted into torpedo plastic pots $30 \mathrm{~cm}$ containing a mixture of sand: peat: vermiculite: perlite with difference ratio (by volume) (1:1:1:1), (2:1:1:1), (2:2:1:1) and (1:2:1:1), Plantlets were grown in greenhouse condition and covered with clear polyethylene bag for four weeks, the polyethylene bags were progressively removed after two weeks. The plantlets were sprayed with MS medium salts solutions at half strength weekly. Survival percentages were recorded after nine weeks from transplanting. This experiment contained 4 medium mixtures as 4 treatments. Experiment was harmonious in a completely randomized design. Every treatment include 3 replicates and each replicate contained one torpedo pot, each torpedo pot contained one plantlet. 

by immature inflorescences

\subsection{Data taken and statistical analysis}

Each treatment contains three replicates, each one replicate represented by three explants or jars. Recorded data were analyzed by Analysis of Variance (ANOVA) using MSTAT method. Duncan's multiple rang test was employed for mean comparisons accord to Snedecor and Cochran (1982).

\section{Results and Discussions}

\subsection{Establishment stage}

\subsubsection{Sterilization procedure experiment}

3.1.1.1 Effect of different silver and chitosan nanoparticles concentration on contamination percentages, browning degree \& survival percentage of date palm cv. Barhee immature inflorescences

Data offered in Table 1 exhibit, the effect of different silver \& chitosan nanoparticles concentration on total contamination percentages, browning degree and survival percentage of date palm cv. Barhee immature inflorescences. Results showed that the lowest significant total contamination percentage with nano silver particles at $100,200 \mathrm{mg} / \mathrm{l}$, and nano chitosan at $150,200 \mathrm{mg} / \mathrm{l}$ without significant differences among them. On the other hand, the highest values were occurred with commercial bleach clorox at $30 \%$ and ethanol $70 \%$ nano silver particles at $50 \mathrm{mg} / \mathrm{l}$, chitosan at $50 \mathrm{mg} / \mathrm{l}$, clorox \& ethanol with $\mathrm{MC}$ at $200 \mathrm{mg} / \mathrm{l}$. As for the effect of silver and chitosan nano particles on browning degree, results indicated that the lowest degrees of browning were noticed with nano silver at $50 \mathrm{mg} / \mathrm{l}$. The highest survival percentage was noticed with silver nano particles at $200 \mathrm{mg} / \mathrm{l}$ and nano chitosan particles at 100, 150\& $200 \mathrm{mg} / \mathrm{l}$, without significant differences.

Data presented in Table 2 showed that, the effect of auxin type, concentration, silver and chitosan nanoparticles added to MS medium on contamination percentage, browning degree and survival percentage, results refers that the lowest value of contamination \% occurs with added silver nanoparticles at $4.0 \mathrm{mg} / \mathrm{l}+\mathrm{NAA}$ at $100.0 \mathrm{mg} / \mathrm{l}$. moreover, the lowest value of browning degree with treatment $1 \mathrm{mg} / \mathrm{l}$ silver nanoparticles with 2,4-D 5.0 $\mathrm{mg} / \mathrm{l}$ and $3.0 \mathrm{mg} / \mathrm{l}$ silver nanoparticles with 2,4-D $50.0 \mathrm{mg} / \mathrm{l}$ and $1 \mathrm{mg} / \mathrm{l}$ nano chitosan with NAA at 5 $\mathrm{mg} / \mathrm{l}$. On the contrary, the highest total ontamination was achieved with MS free hormones without nanoparticles.
The highest survival percentage was occurred with $4 \mathrm{mg} / \mathrm{l} \mathrm{N} . \mathrm{S}$. + NAA $100.0 \mathrm{mg} / \mathrm{l}$ and $4 \mathrm{mg} / \mathrm{l} \mathrm{N}$.chito + 2,4-D $100.0 \mathrm{mg} / \mathrm{l}$, without any significant differences among them.

Results indicated that, use of nano particles of silver and chitosan as immersion and adding to culture media controlled of internal and external contamination fungal and bacterial in explants. The current study of date palm indicated that nanoparticles silver and chitosan solution as immersion and adding to culture media significantly reduces contamination internal and external of date palm explant compared to colorx, mercuric chloride and they are not effect of viability of explant and callus culture compare with Clorox and mercuric chloride. Since the activity of silver is greatly influenced by timing of application, preventative applications of silver nanoparticles and ions work better before spores penetrate and colonize within the tissue of plant. Role of the activity of silver on different species of pathogens like soil borne sterile fungi that rarely produce spores Jo et al (2009).

The results gained from this study are consistent with Kamaran Safavi (2012) who indicated that, nano silver and Titanum oxide (TiO2) had a good potential for removing the bacterial contamination in plant tissue culture procedures of potato (Solanum tuberosum $\mathrm{L}$.). He referred that combine nano silver (50 $\mathrm{mg} / \mathrm{l})$ to media and evaluate at second week was fully effective to control the microorganism infection. This research shows that NS had a good potential for removing of the bacterial contaminants in tissue culture plant procedures. Antibiotics have been extensively tested for their ability to inhibit or prevent the growth of bacteria in plant in vitro cultures. However, using of antibiotics has confirmed limitations. For example, antibiotics are expensive; their range of activity against kinds of bacteria is often narrow, usually are heat-labile, phytotoxic and only effective against bacteria and not fungi or do it another way, capable of altering the behavior of cultured plant tissues by default and inhibition of plant growth.

The results showed that NS nano silver particles can reduce and remove microorganisms in MS media and then the explants can growth very well. Cell division inhibition and damage to bacterial cell wrapper are also recorded by (Richards et al 1984) and interaction with hydrogen bonding processes had been demonstrated to take place (Russell \& Hugo 1994). As specific surface area of nanoparticles is increased, their biological effectiveness can be increased due to the increase in surface energy (Willems 2005). Also, Rostami and Shahsavar (2009) recommended adding low concentration of nano silver particles to in vitro media culture of woody plant such as Olive cv. Mission. 
Table 1. Effect of different silver and chitosan nanoparticles concentration on contamination percentages, browning degree \& Survival percentage of date palm cv. Barhee immature inflorescences

\begin{tabular}{|c|c|c|c|}
\hline Treatments $(\mathrm{mg} / \mathrm{l})$ & contamination \% & Browning degree & Survival \% \\
\hline Nano silver at 50.0 & $60.0 \mathrm{AB}$ & $8.0 \mathrm{C}$ & $40.0 \mathrm{C}$ \\
Nano silver at 100.0 & $32.0 \mathrm{C}$ & $16.0 \mathrm{~B}$ & $68.0 \mathrm{~B}$ \\
Nano silver at 200.0 & $24.0 \mathrm{C}$ & $24.0 \mathrm{AB}$ & $76.0 \mathrm{~A}$ \\
Nano chitosan at 50.0 & $72.0 \mathrm{~A}$ & $20.0 \mathrm{~B}$ & $28.0 \mathrm{D}$ \\
Nano chitosan at 100.0 & $48.0 \mathrm{~B}$ & $28.0 \mathrm{~A}$ & $52.0 \mathrm{C}$ \\
Nano chitosan at 150.0 & $29.3 \mathrm{C}$ & $28.0 \mathrm{~A}$ & $70.7 \mathrm{AB}$ \\
Nano chitosan at 200.0 & $20.0 \mathrm{C}$ & $28.0 \mathrm{~A}$ & $80.0 \mathrm{~A}$ \\
Commercial bleach clorox at 30\% and \\
ethanol 70\%
\end{tabular}

Means in each column with similar letter (s) are not significantly different at $5 \%$ level.

Table 2. Effect of auxin type, concentration, silver, and chitosan nanoparticles concentration added to MS medium on contamination percentage, browning degree \& survival percentage of date palm cv. Barhee immature inflorescences

\begin{tabular}{|c|c|c|c|c|c|}
\hline \multirow[b]{2}{*}{$\begin{array}{l}\text { Treatments } \\
(\mathrm{mg} / \mathrm{l})\end{array}$} & \multicolumn{3}{|c|}{ Contamination \% } & \multirow[b]{2}{*}{$\begin{array}{l}\text { Browning } \\
\text { degree }\end{array}$} & \multirow[b]{2}{*}{$\begin{array}{c}\text { Survival } \\
\%\end{array}$} \\
\hline & $\begin{array}{c}\text { Fungal } \\
\%\end{array}$ & $\begin{array}{c}\text { Bacterial } \\
\%\end{array}$ & $\begin{array}{c}\text { Total contamination } \\
\%\end{array}$ & & \\
\hline N.S at $1.0+2,4-\mathrm{D}$ at 5 & $24.0 \mathrm{BCD}$ & $24.0 \mathrm{~B}$ & $48.0 \mathrm{C}$ & $8.0 \mathrm{C}$ & $52.0 \mathrm{C}$ \\
\hline N.S. at $2.0+2,4-D$ at 10 & $12.0 \mathrm{CD}$ & $12.0 \mathrm{CD}$ & $24.0 \mathrm{D}$ & $16.0 \mathrm{~B}$ & $76.0 \mathrm{~A}$ \\
\hline N.S. at $3.0+2,4-D$ at 50 & $12.0 \mathrm{CD}$ & $12.0 \mathrm{CD}$ & $24.0 \mathrm{D}$ & $8.0 \mathrm{C}$ & $76.0 \mathrm{~A}$ \\
\hline N.S. at $4.0+2,4-D$ at 100 & $12.0 \mathrm{CD}$ & $12.0 \mathrm{CD}$ & $24.0 \mathrm{D}$ & $16.0 \mathrm{~B}$ & $76.0 \mathrm{~A}$ \\
\hline N.chito. at $1.0+\mathrm{NAA}$ at 5.0 & $36.0 \mathrm{AB}$ & $28.0 \mathrm{~B}$ & $64.0 \mathrm{~B}$ & $8.0 \mathrm{C}$ & $36.0 \mathrm{D}$ \\
\hline N.chito at $2.0+\mathrm{NAA}$ at 10 & 24.0 BCD & $28.0 \mathrm{~B}$ & $52.0 \mathrm{C}$ & $12.0 \mathrm{BC}$ & $48.0 \mathrm{C}$ \\
\hline N.chito. at $3.0+N A A$ at 50 & $16.0 \mathrm{BCD}$ & $24.0 \mathrm{~B}$ & $40.0 \mathrm{C}$ & $24.0 \mathrm{~A}$ & $60.0 \mathrm{~B}$ \\
\hline N.chito.at $4.0+\mathrm{NAA}$ at 100 & $12.0 \mathrm{CD}$ & $16.0 \mathrm{C}$ & $28.0 \mathrm{D}$ & $28.0 \mathrm{~A}$ & $72.0 \mathrm{~A}$ \\
\hline N.S. at $1.0+$ NAA at 5 & 20.0BCD & $20.0 \mathrm{BC}$ & $40.0 \mathrm{C}$ & $12.0 \mathrm{BC}$ & $60.0 \mathrm{~B}$ \\
\hline N.S. at $2.0+N A A$ at 10 & 12.0CD & $16.0 \mathrm{C}$ & $28.0 \mathrm{D}$ & $12.0 \mathrm{BC}$ & $72.0 \mathrm{~A}$ \\
\hline N.S. at $3.0+N A A$ at 50 & $12.0 \mathrm{CD}$ & $12.0 \mathrm{CD}$ & $24.0 \mathrm{D}$ & $24.0 \mathrm{~A}$ & $75.0 \mathrm{~A}$ \\
\hline N.S. at $4.0+$ NAA 100 & $8.0 \mathrm{D}$ & $8.0 \mathrm{D}$ & $16.0 \mathrm{E}$ & $28.0 \mathrm{~A}$ & $84.0 \mathrm{~A}$ \\
\hline N.chito. at $1.0+2,4-\mathrm{D}$ at 5 & $32.0 \mathrm{BC}$ & $20.0 \mathrm{C}$ & $52.0 \mathrm{C}$ & $12.0 \mathrm{BC}$ & $48.0 \mathrm{C}$ \\
\hline N.chito. at $2.0+2,4-\mathrm{D}$ at 10 & $12.0 \mathrm{CD}$ & $16.0 \mathrm{C}$ & $28.0 \mathrm{D}$ & $12.0 \mathrm{BC}$ & $72.0 \mathrm{~A}$ \\
\hline N.chito.at $3.0 .+2,4-\mathrm{D}$ at 50 & $12.0 \mathrm{CD}$ & $12.0 \mathrm{CD}$ & $24.0 \mathrm{D}$ & $24.0 \mathrm{~A}$ & $75.0 \mathrm{~A}$ \\
\hline N.chito. at $4.0+2,4-$ Dat 100 & $12.0 \mathrm{CD}$ & $8.0 \mathrm{D}$ & $20.0 \mathrm{D}$ & $28.0 \mathrm{~A}$ & $80.0 \mathrm{~A}$ \\
\hline $\begin{array}{c}\text { MS free hormones without } \\
\text { nano particles }\end{array}$ & $44.0 \mathrm{~A}$ & $52.00 \mathrm{~A}$ & $96.0 \mathrm{~A}$ & $16.0 \mathrm{~B}$ & $4.0 \mathrm{E}$ \\
\hline
\end{tabular}

Means in each column with similar letter (s) are not significantly different at $5 \%$ level.

The results in this study referred that using in culture medium after surface sterilization by sodium hypochlorite compared with immersion explants in alcohol following submerge in nano silver particles NS solution was more effective to reduce both of fungal and bacterial contaminations as well as had less adverse effects on viability and regeneration of explants. Our results agreed with those obtained by Kamaran Safavi et al (2011) who reported that using nano silver in culture medium after surface sterilization displayed a more noticeable effect on removing contaminations fungal and bacterial in Tobacco plants tissue culture. 

by immature inflorescences

3.1.1.2 Effect of auxin type \& concentration on callus formation percentage and callus size of date palm cv. Barhee immature inflorescences during establishment stage

Data presented in Table 3 showed, impact of auxin type \& concentration on callus formation percentage and callus size of date palm cv. Barhee immature inflorescences during initiation stage. The highest percentages of callus formation were registered ( $80.0 \& 72.0)$ with treatments of picloram at 8 and $6 \mathrm{mg} / \mathrm{l}$, respectively. The highest value of callus size (2.8 \& 2.6) was noticed with picloram at $8 \& 6$ $\mathrm{mg} / \mathrm{l}$, respectively. The lowest values of callus formation percentage were recorded with picloram at $2.0 \mathrm{mg} / \mathrm{l}$ (36.0), 2,4-D at $4.0 \mathrm{mg} / \mathrm{l}$ (24.0) \& with NAA at $4.0,10.0 \mathrm{mg} / \mathrm{l}(32.0)$ without significant differences among them.

Table 3. Effect of auxin type \& concentration on callus formation percentage and callus size of date palm cv. Barhee immature inflorescences during initiation stage

\begin{tabular}{|c|c|c|}
\hline $\begin{array}{c}\text { Treatments } \\
(\mathbf{m g} / \mathbf{l})\end{array}$ & $\begin{array}{c}\text { Callus } \\
\text { formation } \\
\%\end{array}$ & $\begin{array}{c}\text { Callus } \\
\text { size }\end{array}$ \\
\hline Picloram at 2.0 & $36.0 \mathrm{CD}$ & $1.8 \mathrm{BCD}$ \\
Picloram at 4.0 & $56.0 \mathrm{~B}$ & $1.6 \mathrm{CD}$ \\
Picloram at 6.0 & $72.0 \mathrm{AB}$ & $2.6 \mathrm{AB}$ \\
Picloram at 8.0 & $80.00 \mathrm{~A}$ & $2.8 \mathrm{~A}$ \\
$2,4-\mathrm{D}$ at 4.0 & $24.0 \mathrm{D}$ & $1.2 \mathrm{D}$ \\
$2,4-\mathrm{D}$ at 10.0 & $40.0 \mathrm{C}$ & $2.2 \mathrm{ABC}$ \\
$2,4-\mathrm{D}$ at 15.0 & $44.0 \mathrm{C}$ & $2.4 \mathrm{ABC}$ \\
$2,4-\mathrm{D}$ at 25.0 & $44.0 \mathrm{C}$ & $2.6 \mathrm{AB}$ \\
NAA at 4.0 & $32.0 \mathrm{D}$ & $1.2 \mathrm{D}$ \\
NAA at 10.0 & $32.0 \mathrm{D}$ & $1.6 \mathrm{CD}$ \\
NAA at 20.0 & $56.0 \mathrm{~B}$ & $2.4 \mathrm{ABC}$ \\
\hline
\end{tabular}

Means in every column with similar letter (s) are not significantly different at $5 \%$ level.

3.1.1.3 Effect of auxin and cytokinins concentration on callus weight, callus size \& browning degree of date palm cv. Barhee immature inflorescences during callus proliferation stage

Data in Table 4 pointed out; the highest value of callus weight (9.2) and highest value of callus size (4.0) were occurred with NAA at $10.0 \mathrm{mg} / \mathrm{l}+2 \mathrm{ip}$ at 6 $\mathrm{mg} / \mathrm{l}+\mathrm{kin}$ at $6 \mathrm{mg} / \mathrm{l}$. On a contrary, the lowest values of callus weight and callus size were observed with $\mathrm{NAA}$ at $5.0 \mathrm{mg} / \mathrm{l}+2 \mathrm{ip}$ at $6.0 \mathrm{mg} / \mathrm{l}+\mathrm{kin}$ at $3.0 \mathrm{mg} / \mathrm{l}$. The lowest browning degree (1.0) occurred with NAA at $5.0 \mathrm{mg} / \mathrm{l}+2 \mathrm{ip}$ at $3.0 \mathrm{mg} / \mathrm{l}+\mathrm{kin}$ at $3.0 \mathrm{mg} / \mathrm{l}$, NAA at $5.0 \mathrm{mg} / \mathrm{l}+2 i p$ at $6.0 \mathrm{mg} / \mathrm{l}+\mathrm{kin}$ at $0.0 \mathrm{mg} / \mathrm{l}$ and NAA at $5.0 \mathrm{mg} / \mathrm{l}+2 \mathrm{ip}$ at $6.0 \mathrm{mg} / \mathrm{l}+\mathrm{kin}$ at $6.0 \mathrm{mg} / \mathrm{l}$ without significant differences among them.
Many reports showed that, the combination of auxin like NAA and cytokinins has a significantily effective on regeneration of plant. The cytokinins which encourage cell division in plant and have active role on maturation of callus and embryos. Some of researchers believed that auxins such as 2,4-dichlorophenoxy acetic acid (2,4-D), naphthalene acetic acid (NAA), Picloram, Dicamba, 2,4,5-tricholorophenoxy acetic acid (2,4,5 T) and endogenous hormone metabolism which are influenced by genetic, physiological \& environmental signal play a key role in somatic embryogenesis in different plant species (Rao 1996; Dodeman et al 1997; Feher 2006). Kurup (2014). Who reported that, the combination of BAP with NAA is thinked to be the potential factor to devise a rapid response of callus induction of date palm cv. Khenizi. Junaid et al (2009) reported that, the maximum callus induction was observed in date palm cv. 'Khalasah' follow up by 'Zadai' \& 'Muzati' on MS medium add up to 2,4-D at 1.5 $\mathrm{mg} / \mathrm{l}$. The active concentration, however, varied in rranged from 0.5 to $1.5 \mathrm{mg} / \mathrm{l}$; but, the higher concentration inhibit callus induction and growth.

The highest $\%(90.0 \%)$ of bud explants producing callus of date palm cv. Najda was observed on MS medium supplemented with $45 \mu \mathrm{M}$ 2,4-D and $4.5 \mu \mathrm{M} 2 \mathrm{iP}$. Explants from bud-derived were displayed a high embryogenic potential when cultured on MS medium supplemented with 2,4-D or picloram (Mazri et al 2017).

When Malht et al (2019) indicated, the higher significant callus formation percentage of date palm cv. Sewi were obtained with 2,4-D and picloram at $4 \mathrm{mg} / \mathrm{l}$, the higher embryo formation of date palm cv. Sewi with MS medium supplemented with Picloram at $4 \mathrm{mg} / \mathrm{l}$.

\subsection{Multiplication Stage}

3.2.1 Effect of Fe and Zn nanoparticles concentration added to MS culture medium on number of shoots/culture \& average shoot length $(\mathrm{cm})$ of date palm cv. Barhee callus culture during shoot formation stage

In Table 5 data indicated, the highest number of shoot / culture $(7.4,7.2 \& 6.4)$ was occurred with MS medium supplemented by $\mathrm{Fe}$ nano particles at $20.85 \mathrm{mg} / \mathrm{l}$, MS medium supplemented by Fe nano particles $27.8 \mathrm{mg} / \mathrm{l}$, and MS supplemented $\mathrm{Zn}$ nano particles at $4.3 \mathrm{mg} / \mathrm{l}$ in the first subculture without any significant differences among them. The results took the same trend in the second and third subculture. On the other hand, control MS without either $\mathrm{Fe}$ or $\mathrm{Zn}$ nanoparticles gave the lowest values in the three subcultures. 
Table 4. Effect of auxin and cytokinins concentration on callus weight, callus size\& browning degree of date palm cv. Barhee immature inflorescences during callus proliferation stage

\begin{tabular}{|c|c|c|c|}
\hline $\begin{array}{c}\text { Treatments } \\
(\mathbf{m g} / \mathbf{l})\end{array}$ & Callus weight & Callus Size & Browning degree \\
\hline NAA at 5.0+2ip 3.0+kin 3.0 & $3.9 \mathrm{C}$ & $1.6 \mathrm{DE}$ & $1.0 \mathrm{C}$ \\
NAA at 5.0+2ip 6.0+kin 0.0 & $4.0 \mathrm{C}$ & $2.2 \mathrm{CD}$ & $1.0 \mathrm{C}$ \\
NAA at 5.0+2ip 6.0+kin 6.0 & $6.2 \mathrm{~B}$ & $2.8 \mathrm{BC}$ & $1.0 \mathrm{C}$ \\
NAA at 5.0+2ip 6.0+kin 3.0 & $3.1 \mathrm{C}$ & $1.4 \mathrm{E}$ & $2.0 \mathrm{AB}$ \\
NAA at 10.0+2ip 3.0+kin 3.0 & $4.1 \mathrm{C}$ & $1.8 \mathrm{DE}$ & $2.2 \mathrm{~A}$ \\
NAA at 10.0+2ip 6.0+kin 0.0 & $4.4 \mathrm{C}$ & $2.0 \mathrm{DE}$ & $1.6 \mathrm{ABC}$ \\
NAA at 10.0+2ip 6.0+kin 3.0 & $6.1 \mathrm{~B}$ & $3.2 \mathrm{~B}$ & $1.4 \mathrm{BC}$ \\
NAA at 10.0+2ip 6.0+kin 6.0 & $9.2 \mathrm{~A}$ & $4.0 \mathrm{~A}$ & $1.6 \mathrm{ABC}$ \\
NAA at 20.0+2ip 3.0+kin 3.0 & $6.3 \mathrm{~B}$ & $3.2 \mathrm{~B}$ & $1.6 \mathrm{ABC}$ \\
\hline
\end{tabular}

Means in every column with similar letter (s) are not significantly different at $5 \%$ level.

Table 5. Effect of Fe and $\mathrm{Zn}$ nanoparticles concentration adding to MS culture medium on number of shoots/culture and average shoot length $(\mathrm{cm})$ of date palm cv. Barhee callus culture during shoot formation stage

\begin{tabular}{|c|c|c|c|c|c|c|}
\hline \multirow{2}{*}{ Treatments $(\mathrm{mg} / \mathrm{l})$} & \multicolumn{3}{|c|}{ N. of shoots /culture } & \multicolumn{3}{|c|}{ Average shoot length $(\mathrm{cm})$} \\
\hline & $1^{\text {st }}$ sub. & $2^{\text {nd }}$ sub. & $3^{\text {rd }}$ sub. & $1^{\text {st }}$ sub. & $2^{\text {nd }}$ sub. & $3^{\text {rd }}$ sub. \\
\hline MS medium & $3.4 \mathrm{D}$ & $3.4 \mathrm{C}$ & $2.6 \mathrm{D}$ & $3.56 \mathrm{CD}$ & $3.00 \mathrm{D}$ & $3.50 \mathrm{BC}$ \\
\hline MS + Fe N.Ps at 6.95 & $3.6 \mathrm{D}$ & $4.0 \mathrm{BC}$ & $3.2 \mathrm{CD}$ & $3.70 \mathrm{CD}$ & 3.80 CD & $3.40 \mathrm{BC}$ \\
\hline MS+ Fe N.Psat13.9 & $5.2 \mathrm{BC}$ & $5.0 \mathrm{~B}$ & $4.2 \mathrm{BC}$ & $4.60 \mathrm{BC}$ & $4.84 \mathrm{ABC}$ & 4.30 ABC \\
\hline MS+ Fe N.Ps at 20.85 & $7.4 \mathrm{~A}$ & $6.8 \mathrm{~A}$ & $4.8 \mathrm{AB}$ & $6.26 \mathrm{~A}$ & $5.42 \mathrm{AB}$ & $4.66 \mathrm{ABC}$ \\
\hline MS+ Fe N.ps at 27.8 & $7.2 \mathrm{~A}$ & $7.8 \mathrm{~A}$ & $5.8 \mathrm{~A}$ & $6.28 \mathrm{~A}$ & $6.10 \mathrm{~A}$ & $5.80 \mathrm{~A}$ \\
\hline $\mathrm{MS}+\mathrm{Zn} \mathrm{N} . \mathrm{Ps}$ at 2.15 & $3.8 \mathrm{CD}$ & $4.2 \mathrm{BC}$ & $3.0 \mathrm{CD}$ & $3.80 \mathrm{CD}$ & $4.20 \mathrm{BCD}$ & 3.20 \\
\hline MS+Zn N.Ps at 4.3 & $6.4 \mathrm{AB}$ & $6.8 \mathrm{~A}$ & $5.0 \mathrm{AB}$ & $5.88 \mathrm{AB}$ & $6.06 \mathrm{~A}$ & $4.80 \mathrm{AB}$ \\
\hline $\mathrm{MS}+\mathrm{Zn}$ N.Ps at 6.45 & $3.0 \mathrm{D}$ & $4.2 \mathrm{BC}$ & $3.2 \mathrm{CD}$ & $3.00 \mathrm{D}$ & $4.20 \mathrm{BCD}$ & $3.40 \mathrm{BC}$ \\
\hline MS+ Zn N.ps at 8.6, & $3.4 \mathrm{D}$ & $4.2 \mathrm{BC}$ & $3.2 \mathrm{CD}$ & $3.86 \mathrm{CD}$ & 4.20 BCD & $3.80 \mathrm{BC}$ \\
\hline
\end{tabular}

Means in every column with similar letter (s) are not significantly different at $5 \%$ level.

Data in Table 5 illustrated that, the highest average shoot length $(\mathrm{cm})(6.28,6.26 \& 5.88)$ was obtained with MS medium supplemented by Fe nano particles at $27.85 \mathrm{mg} / \mathrm{l}, \mathrm{MS}$ medium supplemented by $\mathrm{Fe}$ nano particles at $20.8 \mathrm{mg} / \mathrm{l}$, and MS supplemented $\mathrm{Zn}$ nano particles at $4.3 \mathrm{mg} / \mathrm{lin}$ the first subculture without any significant differences among them. The results took the same trend in the second and third subculture.
Results cleared that nanoparticles of Fe and $\mathrm{Zn}$ added to culture media are significantly increase the number of shoots per culture \& average shoot length $(\mathrm{cm})$ of date palm $\mathrm{cv}$. Barhee callus culture compared with MS medium free nanoparticles. Good shooting, rooting \& regenerated plantlets of banana $s p$. were spotted also in MS+Zinc nanoparticles and $\mathrm{ZnO}$ at $100 \mathrm{mg} / \mathrm{L}$. The nanoparticles led to accumulation of both proline and chlorophyll and 

by immature inflorescences

the activity of antioxidant enzymes and developed more dry weight accumulation than the control (Helaly et al 2014). Silver nanoparticles, BAP at 40 $\mathrm{mg} / \mathrm{l}$ and IAA at $20 \mathrm{mg} / \mathrm{l}$ gave the highest \% of explants per shoots and highest mean number \& length of shoots per explants of Tecomella undulate (Roxb) Aghdaei et al (2012).

Zaho et al (2014) reported that using Zn, Fe and $\mathrm{Cu}$ oxide NPs at $50 \mathrm{ppm}$ as foliar spray enhancement the shoot growth and length of Vigina radiate. Zinc oxide NPs at $400 \mathrm{mg} / \mathrm{Kg}$ enhancing the uptake of micronutrients of $\mathrm{Cu}, \mathrm{Mn}$ and $\mathrm{Zn}$ of Cucumis sativus fruits.

3.2.2 Effect of auxin \& cytokinins concentration on number of shoot per culture of date palm Barhee callus culture during shoot multiplication stage

Effect of auxin concentration, the highest significant number of shoots/culture (4.24, 4.08 and 3.44) were achieved by NAA at $4.0 \mathrm{mg} / \mathrm{l}$ in the $1^{\text {st }}, 2^{\text {nd }}$ and $3^{\text {rd }}$ subculture, respectively. Meanwhile, the lowest values were noticed with NAA at 0.0 or $0.5 \mathrm{mg} / \mathrm{l}$.

The effects of cytokinins, the highest number of shoots/culture were recorded by $2 \mathrm{ip}+\mathrm{kin}$ at 2.0 or $4.0 \mathrm{mg} / \mathrm{l}$. On a contrary, control treatment $(0.0 \mathrm{mg} / \mathrm{l})$ gave the lowest values during the three subcultures. The interaction between cytokinin \& auxin concentration, the highest number of shoots / culture $(6.60$ \& 5.60) $(6.40,5.20)$ and $(5.20,4.80)$ were achieved with NAA at $2.0 \mathrm{mg} / \mathrm{l}, 2 \mathrm{ip}$ at $4 \mathrm{mg} / \mathrm{l}$, kin at $4 \mathrm{mg} / \mathrm{l}$ and $\mathrm{NAA}$ at $4.0 \mathrm{mg} / \mathrm{l}$, 2ip at $4.0 \mathrm{mg} / \mathrm{l}$, kin at $4.0 \mathrm{mg} / \mathrm{l}$ respectively, without any significant differences among them in first, second and third subcultures. Otherwise, the lowest number of shoots / culture in first, second and third subculture (1.0 j) was occurred with NAA at $0.0 \mathrm{mg} / \mathrm{l}$, with 2ip \& kin at $0.5 \mathrm{mg} / \mathrm{l}$ of first subculture.

3.2.3 Effect of auxin and cytokinins concentration on average shoots length $(\mathrm{cm})$ of date palm cv. Barhee callus culture during shoot multiplication stage

Effect of auxin concentration, data in Table 7. Pointed that, the highest average shoot length $(\mathrm{cm})$ (6.1, 5.2 and 5.3) was occurred with auxin treatment by NAA at $4.0 \mathrm{mg} / \mathrm{l}$ in the $1^{\text {st }}, 2^{\text {nd }} \& 3^{\text {rd }}$ subcultures. The lowest average shoot length $(\mathrm{cm})(3.50,2.7$, 2.8) was recorded with NAA at $0.0 \mathrm{mg} / \mathrm{l}$ respectively, without any significant differences among them in the $1^{\text {st }}, 2^{\text {nd }}$ and $3^{\text {rd }}$ subcultures.
3.2.4 Effect of cytokinin concentration, there are insignificant differences among them all the cytokinins treatments in the $1^{\text {st }}, 2^{\text {nd }}$ and $3^{\text {rd }}$ subcultures of average shoot length $(\mathrm{cm})$.

The interaction between cytokinin and auxin concentration, the highest average shoot length (cm) (6.2 and 6.6) were achieved with NAA at 4.0 and $2.0 \mathrm{mg} / \mathrm{l}$ with 2ip at $4.0 \mathrm{mg} / \mathrm{l}$, kin at $4.0 \mathrm{mg} / \mathrm{l}$, respectively, without any significant differences among them in $1^{\text {st }}$ and $3^{\text {rd }}$ subcultures. On a contrary, the lowest average shoot length $(\mathrm{cm})(2.2,2.0$ and 1.8) was occurred with NAA at $0.0,1.0$ \& $2.0 \mathrm{mg} / \mathrm{l}$, with 2ip \& kin at $0.5 \mathrm{mg} / \mathrm{lin}$ first, second and third subcultures.

Pervious studies In vitro in date palm immature inflorescences effected by multifaceted factors like light, photoperiod, $\mathrm{pH}$ of the medium, and nutrients. Many studies have also converge on the effect of plant growth regulators on in vitro flowering process in other species (Jain et al 2011). The significantly effective of cytokinins on in vitro mature inflorescences was well-celebrated and-comprehended in the literature (Wang et al 2001). The action of BA (6-benzyladenine) or combined impact of BA with phytohormones on early in vitro has inflorescences also been reported for different plant species (Hee et al 2007).

The previous results pointed that, the use of 2iP at $1.5 \mathrm{mg} / \mathrm{l}, \mathrm{BAP}$ at $1 \mathrm{mg} / \mathrm{l}$ and NAA at $1 \mathrm{mg} / \mathrm{l}$ give the highest mean number of shoot per explant and highest mean shoot length of date plam cv. Barhee (Jazinizadeh et al 2015). Similarly, MasmoudiAllouche et al (2010) resulted, an in vitro flower induction experiment of one year old date palm cv. Barhee plantlets which was hold on basal MS medium, with sucrose $(50 \mathrm{~g} / \mathrm{l})$ \& phytohormones (NAA: $2.68 \mu \mathrm{M}$, BAP: $4.44 \mu \mathrm{M}$, Kin: $4.64 \mu \mathrm{M}$ \& IPA: 5.28 $\mu \mathrm{M})$. Studing on in vitro propagation of date palm $\mathrm{cv}$. Sukry by (Al-khateeb 2006) submitted, the highest propagation was occured in the MS medium, with $0.05 \mathrm{mg} / \mathrm{l} \mathrm{Kin} 0.025 \mathrm{mg} / \mathrm{l}$ 2ip, BAP, IAA, NOA \& NAA. The same results were also obtained by Zaid et al (2006) and Aaouine (2000). In a similar way, Khan and Tabassum (2012) gave this conclusion that after using $3 \mathrm{mg} / \mathrm{l} 2 \mathrm{iP}$ \& BAP at initiation stage, the quantity of cytokinins decreased to $0.5 \mathrm{mg} / \mathrm{K}$ Kin \& BAP respectively. As well, they are revealed that utilizing a conjunction of two cytokinins (BAP \& Kinetin) and one auxin (NAA) in multiplication stage demonstrated more hopeful for making cultures with sufficient mean number of shoots with best shoot 


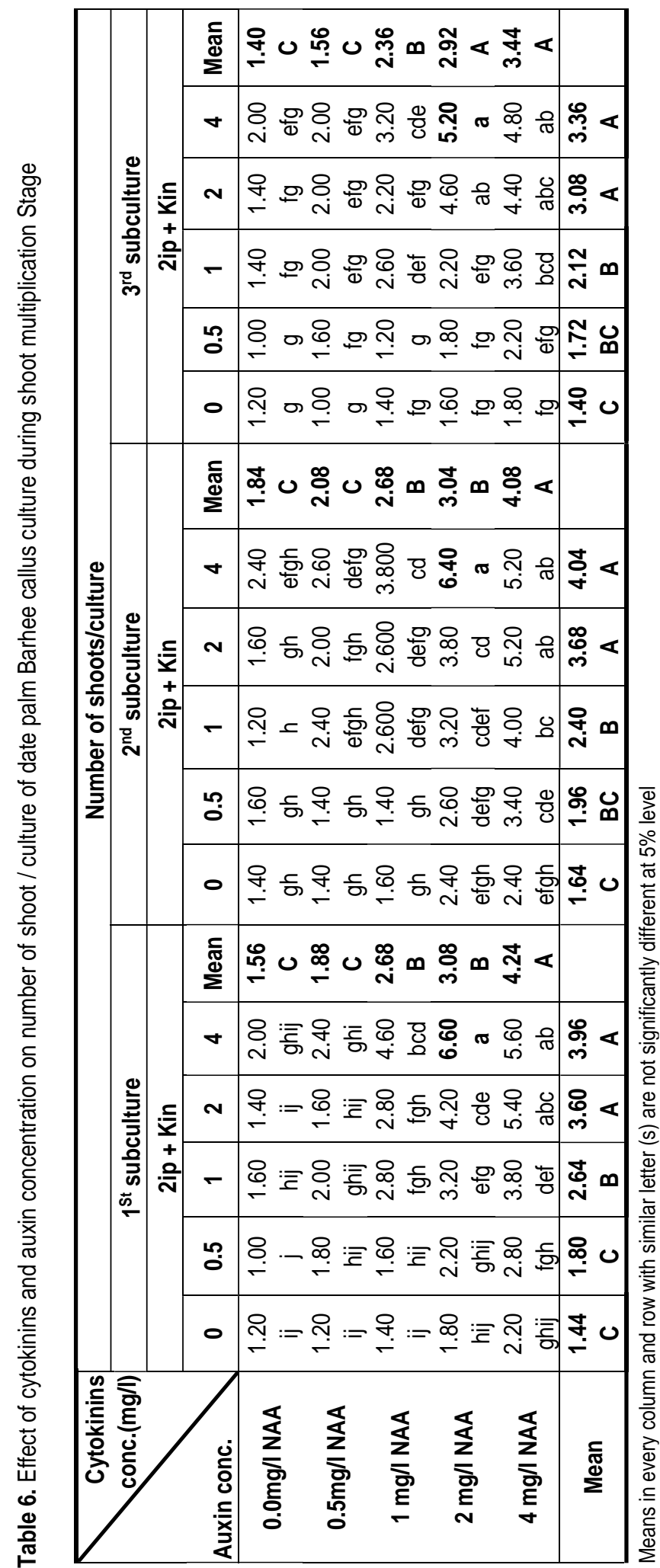




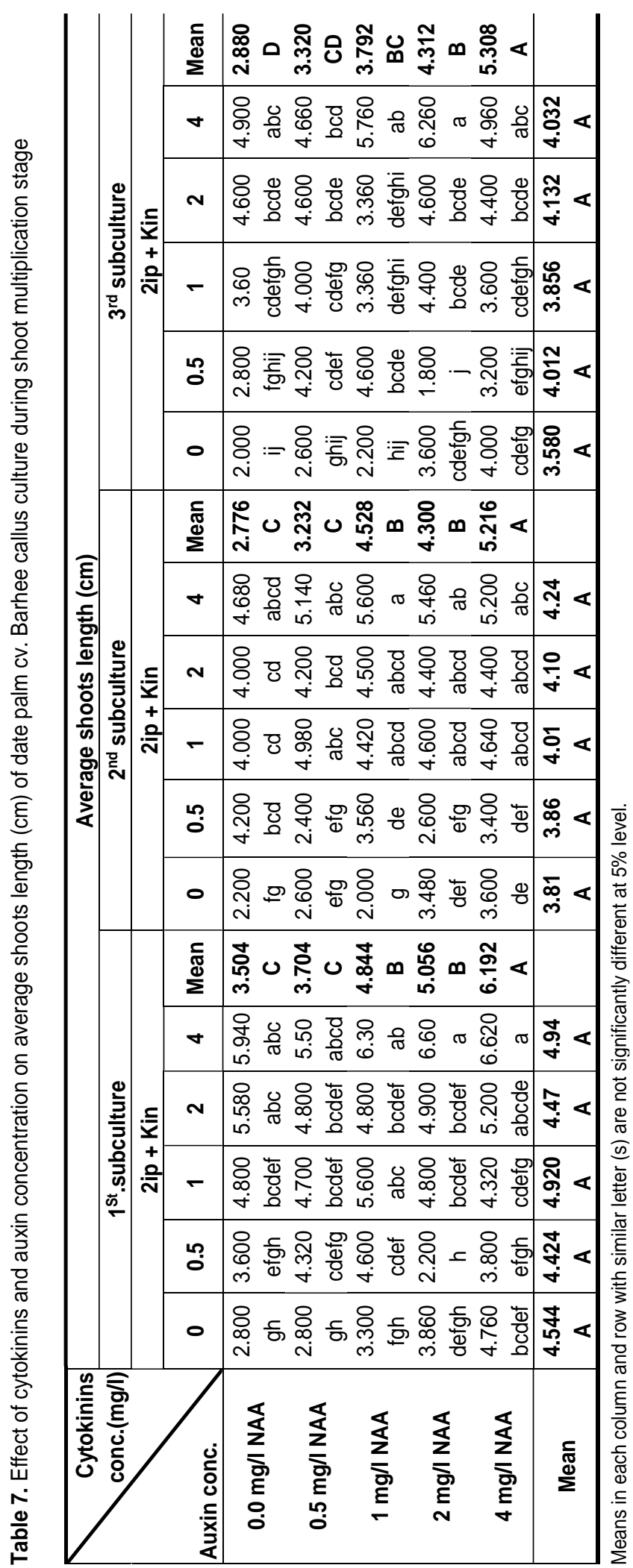


lengths. In present study, shoots good developed adequate (number of shoots per culture \& average shoot length) just after 3 subcultures without increasing, as we used combination of cytokinins (2iP \& Kin) with auxin (NAA).

Similarly results by Malht et al (2019) indicated, Kin at $0.25 \mathrm{mg} / \mathrm{l}$ significant increasing average number of adventitious shoot per culture of date palm cv. Sewi and refereed, Kin and 2ip had gave the highest significant number of shoots per culture.

\subsection{Rooting Stage}

3.3.1 Effect of auxin type \& concentration on rooting percentage, number of roots \& root length $(\mathrm{cm})$ of date palm cv. Barhee microshoots during rooting stage

In Table 8 data illustrated, the highest rooting percentage (83.3) was recorded with MS medium supplemented by NAA at $0.5 \mathrm{mg} / \mathrm{l}$. On the contrary, the lowest rooting percentage (33.3) was showed with MS medium with NAA at $0.2 \mathrm{mg} / \mathrm{l}$ and IBA at $1.0 \mathrm{mg} / \mathrm{l}$. Moreover, the highest number of roots/ microshoots (4.7\& 4.2) was occurred with MS medium with NAA $0.5 \& 1.0 \mathrm{mg} / \mathrm{l}$, respectively. The highest values of root length $(\mathrm{cm})(6.4 \& 5.9)$ were recorded with MS medium with IBA at $3.0 \& 2.0 \mathrm{mg} / \mathrm{l}$.

Thereafter, in order to do the root formation, good developed and normal morphologically regenerated shoots were recultured to MS medium, supplemented with different levels of NAA. Root formation is a essential stage in micropropagation of date palm, as it allow the subsequent success of production of food date palm plantlets (Shaheen, 1990). Our results revealed, the highest rooting percentage \& number of root per microshoots were obtained with NAA at $0.5 \mathrm{mg} / \mathrm{l}$ and IBA at $3.0 \mathrm{mg} / \mathrm{l}$, respectively. Similar of our results with in vitro rooting of date palm was explained by Bekheet (2013) he showed that NAA $(1 \mathrm{mg} / \mathrm{L})$ was the best for in vitro root formation in compar with IAA or IBA with same concentrations. The stimulative effects of NAA treatment on rooting also has been obtained in other explants. Roots efficiently developed when cultured leaf explants of date palm on the Eeuwen's induction medium with $5 \& 15 \mathrm{mg} / \mathrm{L}$ NAA (Asemota et al 2007). On the other hand, Tissert (1984) revealed that unusual rooting of date palm plantlets were gained on medium with $0.1 \mathrm{mg} / \mathrm{L}$ NAA. He was showing that, high levels of NAA in a negative way affected to root length of date palm cv. Barhee plantlets. Helaly et al (2014) showed that, NAA at 1.0 $\mathrm{mg} / \mathrm{L}$ dosage was preferable because it gaving the best effective on encourage the regeneration of plantlets of banana with well-formed root systems.

The highest percentage of rooting $(90.9 \%)$ recorded with NAA $0.5 \mathrm{mg} / \mathrm{l}$ was employed. The highest root number per microshoots were observed in the existence of $1.0 \mathrm{mg} / \mathrm{l} \mathrm{NAA}$ and they decreased as NAA level was decreased (at 0.5 and $0.2 \mathrm{mg} / \mathrm{l}$ ) or increased $(2.0 \mathrm{mg} / \mathrm{l})$ of date palm cv. Barhee (Jazinizadeh et al (2015). Mushtaque et al (2015) indicated that, best rooting in $1 / 4 \mathrm{MS}$ medium with NAA $0.1 \mathrm{mg} / \mathrm{l}$ in absence of activated charchol (AC), in Pakistani date palm cultivars "Gajar", "Kashoowari", and "Dedhi". Elghayaty et al (2016) studied the rooting in "Hayani" after 8 weeks, noticed that a combination of $1.0 \mathrm{mg} / \mathrm{l}$ each of IBA \& NAA in MS medium significantly increase the number of root formations \& root length when one shoot was cultured / test tube.

Similarly results reported, by Malht et al (2019) showed that, NAA $1.0 \mathrm{mg} / \mathrm{L}$ induced the highest rooting percentage \& microshoots length of date palm cv. Sewi microshoots.

Table 8. Effect of auxin type \& concentration on rooting \%, number of roots and root length $(\mathrm{cm})$ of date palm cv. Barhee microshoots during rooting stage

\begin{tabular}{|c|c|c|c|}
\hline $\begin{array}{c}\text { Auxin } \\
\text { treatments } \\
\text { (mg /L) }\end{array}$ & $\begin{array}{c}\text { Rooting } \\
\%\end{array}$ & $\begin{array}{c}\text { Number of } \\
\text { roots/ } \\
\text { microshoots }\end{array}$ & $\begin{array}{c}\text { Root } \\
\text { length } \\
\text { (cm) }\end{array}$ \\
\hline NAA at 0.2 & $33.3 \mathrm{D}$ & $2.2 \mathrm{C}$ & $2.9 \mathrm{~B}$ \\
$\mathrm{NAA}$ at 0.5 & $83.3 \mathrm{~A}$ & $4.7 \mathrm{~A}$ & $4.3 \mathrm{AB}$ \\
$\mathrm{NAA}$ at 1.0 & $66.6 \mathrm{~B}$ & $4.2 \mathrm{AB}$ & $4.0 \mathrm{AB}$ \\
$\mathrm{IBA}$ at 1.0 & $33.3 \mathrm{D}$ & $2.2 \mathrm{C}$ & $4.3 \mathrm{AB}$ \\
$\mathrm{IBA}$ at 2.0 & $50.0 \mathrm{C}$ & $3.2 \mathrm{BC}$ & $5.9 \mathrm{~A}$ \\
$\mathrm{IBA}$ at 3.0 & $66.6 \mathrm{~B}$ & $3.0 \mathrm{BC}$ & $6.4 \mathrm{~A}$ \\
\hline
\end{tabular}

Means in each column with similar letter (s) are not significantly different at $5 \%$ level.

\subsection{Acclimatization stage}

3.4.1 Effect of medium mixtures on survival percentageof date palm cv. Barhee plantlet during acclimatization stage

In Table 9 data indicated that, the highest survival percentage $(83 \& 80)$ were occurred with medium mixtures sand: peat: vermiculite: perlite (1:2: 1:1) and medium mixtures sand: peat: vermiculite: 

by immature inflorescences

perlite (2: 1: 1: 1) respectively, without any significant differences between them of date palm cv. Barhee plantlet. On the contrary, the lowest survival percentage (21.33) was recorded with medium mixtures sand: peat: vermiculite: perlite $(1: 1: 1: 1)$ of date palm cv. Barhee plantlet.

Table 9. Effect of medium mixtures on survival $\%$ of date palm cv. Barhee plantlet during acclimatization stage

\begin{tabular}{|c|c|}
\hline Medium mixture & $\begin{array}{c}\text { Survival } \\
\%\end{array}$ \\
\hline $\begin{array}{c}\text { Sand: Peat: Vermiculite : perlite } 1: \\
\qquad 1: 1: 1\end{array}$ & $21.33 \mathrm{C}$ \\
\hline $\begin{array}{c}\text { Sand: Peat: Vermiculite : perlite } 2 \text { : } \\
\qquad 1: 1: 1\end{array}$ & $80.0 \mathrm{~A}$ \\
\hline $\begin{array}{c}\text { Sand: Peat: Vermiculite : perlite } 2 \text { : } \\
\qquad 2: 1: 1\end{array}$ & $33.3 \mathrm{~B}$ \\
\hline $\begin{array}{c}\text { Sand: Peat: Vermiculite : perlite } 1: \\
2: 1: 1\end{array}$ & $83.0 \mathrm{~A}$ \\
\hline
\end{tabular}

Means in each column with similar letter (s) are not significantly different at $5 \%$ level.

This study and based on the utilization of rooting stage formation of adventitious roots and accurate handling for the plant material, the survival percentage extended to more than $80-83 \%$. Using of medium mixture contained sand: Peatmoss: perlite: vermiculite at ratio $(1: 2: 1: 1)$ and $(2: 2: 1: 1 \mathrm{v} / \mathrm{v})$ gave the best survival percentage in acclimatization stage. Several soil mixtures have been used to transfer plantlets ex vitro.

Rooting superiority of the ex vitro plantlets of date palm was the dynamic factor increased the survival percentage in the greenhouse. Most of the studies registered low survival percentage 25-35\% during acclimatization stage rather than it used to be a big problem in complete micropropagation protocol (Abul-Soad et al 1999; Hegazy and Abo shama 2010; Taha et al 2007).

The major mixture characteristic that effectiveness plant growth is moisture which should not be excessive to escaping fungi attacks roots and not too low to avoid plantlet dryness. Tissert (1984) showed the best survival rate was recorded for 10$12 \mathrm{~cm}$ date palm plantlets transferred to peat moss: vermiculite mixture $(1: 1 \mathrm{v} / \mathrm{v})$ and covered with transparent plastic. El-Sharabasy et al (2001) reported that the best results were occurred with a planting medium containing equivalent parts of peat, sand and vermiculite. Survival percentage was reached to $80 \%$ after eighteen months. The survival percentage of some Pakistani date palm cultivars reached more than $95 \%$. The used soil bed was a simple mixture of washed sand and peatmoss (1:1 volume / volume) with few amount of perlite. The acclimatized plants with at least one compound leaf were shifted to the field conditions (Mushtaque et al (2015) and Gabr and Abd-Alla (2010) indicated that pre-acclimatization is a very useful \& important step to full micropropagation process. Plantlets grown in lab under optimum conditions (moisture, salts, sucrose and water), slim cuticle layer in leaves with high transpiration rate. Water supply must be keep an eye on carefully during the $1^{\text {st }}$ month of acclimatization process. If the moisture are too much can lead to plantlet root and too little moisture in the substrate can lowering the relative humidity around the plants and cause their rapid wilt. Al-Khayri (2010) spotted a survival range of $72-84 \%$ in date palm cvs. Khasab and NaboutSaif. In date palm cv. Najda organogenesis, recorded, the survival rate depends upon the elongation-rooting medium; and a high survival rate of $100 \%$ was recorded in plantlets that have been cultured on plant growth regulators free in solid medium before acclimatization.

Highest survival \% (88-92.5\%) were also obtained in date palm cv. Mejhoul propagated by through organogenesis (Mazri et al 2016).

Also, Malht et al (2019). Indicated, the higher significant survival percentages $(83 \%)$ during acclimatization stage of date palm cv. Sewi were observed with plantlets produced from Indole-3-butyric acid (IBA) at $0.5 \mathrm{mg} / \mathrm{l}$ during rooting stage.

\section{References}

Aaouine, M (2000) Production of date palm in vitro plants: the Moroccan experience. Proceedings of the Date Palm International Symposium, Windhoek, Namibia.

Abul-Soad, AA; Ibrahim, IA; El-Sherbeny, NR; Baker S.I. 1999. In vitro and ex vitro optimization for rooting and acclimatization of date palm. Proc. first Inter. Conf. in Egypt on plant tissue culture and its Application, 12-14 September, Egypt pp 227-241.

Aghdaei, M; Salehi, H; Sarmast, MK (2012) Effects of silver nanoparticles on Tecomellaundulata (Roxb.) Seem Micropropagation. Adv Hort Sci 26, 21-24.

Al-khateeb, AA (2006) Role of cytokinin and auxin on the multiplication stage of date palm (Phoenix dactylifera L.) cv. Sukry. Biotechnology 5, 349-352. 
Al-Khayri, JM (2010) Somatic embryogenesis of date palm (Phoenix dactylifera L.) improved by coconut water. Biotechnology 9, 477-484. doi: 10.3923/biotech.

Asemota, O; Eke, CR; Odewale, JO (2007) Date palm (Phoenix dactylifera L.) in vitro morphogenesis in response to growth regulators, sucrose and nitrogen. African J Biotechnol 6, 2353-2357.

Becker D.K., Dugdale B., Smith M.K., Harding R.M. and Dale J.L. 2000. Genetic transformation of Cavandish banana (Musa spp. AAA group) cv. 'Grand Nain' via microprojectile bombardment. Plant Cell Rep 19, 229-234.

Bekheet, S (2013) Direct organogenesis of date palm (Phoenix dactylifera L.) for propagation of trueto- type plants. Sci Agric 4, 85-92.

Dodeman, VL; Ducreux, G; Kreis, M (1997) Zygotic embryogenesis versus somatic embryogenesis. J Exp Bot 48, 1493-1509.

El-Sharabasy, SF; Bosila, HA; Ibrahim, IA (2001) Micropropagation studies on Zaghlool and Sewicvs of date palm (Phoenix dactylifera L.): III. Plantlet acclimatization. Proceedings second international conference on date palm, Al Ain, UAE. pp. 523-530.

Elghayaty, SH; Edriss, MH; Abdrabboh, GA; Elsharabasy, SF; Abd-El-kariem, GE (2016) An optimized protocol for direct shoot regeneration from shoot tips cultures of date palm (Phoenix dactylifera L.) cv. Hayani. World Rural Observations 8, 91-98.

FAO (2019) FAOSTAT. Food and Agricultural Organization of the United Nations. Available in: www.fao.org/faostat/en/; access In: June 20.

Feher, A (2006) Why somatic plant cells start to form embryos? In: Plant cell monographs. Mujib A., Samaj J. (eds), Springer-Verlag Berlin Heidelberg 2, 85-101.

Gabr, MF; Abd-Alla, MM (2010) Micropropagation of Phoenix dactylifera L. var. Karama. New York Sci J 3, 64-69.

Hee, KH; Loh, CS; Yeoh, HH (2007) Early in vitro flowering and seed production in culture in Dendrobium Chao Praya Smile (Orchidaceae)."Plant Cell Reports 26, 2055-2062.

Hegazy, AE; Aboshama, HM (2010) An efficient novel pathway discovered in date palm micropropagation. Acta Hort 882, 167-176.
Helaly, MN; El-Metwally, MA; El-Hoseiny, H; Abdelaziz, SO; El-Sheery, NI (2014) Effect of nanoparticles on biological contamination of 'in vitro' cultures and organogenic regeneration of banana. Australian J of Crop Sci 8, 612-624.

Jain, SM; Al-Khayri, JM; Johnson, DV (2011) Date Palm Biotechnology. Springer, the Netherlands. pp. 47-68.

Jazinizadeh, E; Zarghami, R; Majd, A; Iranbakhsh, A; Tajaddod, $G$ (2015) In vitro product of date palm (Phoenix dactylifera L.) cv. 'Barhee' plantlets through direct organogenesis. Biol Forum 7, 566572.

Jo, YK; Kim, BH; Jung, G (2009) Antifungal Activity of Silver lons and Nanoparticles on Phytopathogenic Fungi. Plant Dis 93, 1037-1043.

Junaidaslam; Khan, SA (2009) In vitro micropropagation of 'khalas' date palm (Phoenix dactylifera I.), an important fruit plant. $J$ of Fruit and Ornamental Plant Research 17, 15-27.

Kamran, S (2011) In vitro antibacterial activity of nanomaterial for using in tobacco plants tissue culture. World Academy of Sci, Engineering and Technology 55, 372-375.

Kamran, S (2012) Evaluation of Using Nanomaterial in Tissue Culture Media and Biological activity. $2^{\text {nd }}$ International Conference on Ecological, Environmental and Biological Sci. (EEBS'2012) Oct. 13-14, Bali. Indonesia.

Khan, S; Tabassum, BB (2012) Direct shoot regeneration system for date palm (Phoenix dactylifera L.) cv. Dhakki as a means of micropropagation. Pak $J$ Bot 44, 1965-1971.

Kurup, SS (2014) Rapid in vitro regeneration of date palm (Phoenix dactylifera L.) cv. Kheneizi using tender leaf explant. Emirates $J$ of Food and Agric 26, 539-544.

Masmoudi-Allouche, F; Meziou, B; Kriaa^, W; Gargouri-Bouzid, R; Drira, N (2010) In vitro flowering induction in date palm (Phoenix dactylifera L.). J Plant Growth Regul 29, 35-43.

Mazri, MA; Meziani, R; El-Fadile, J; Ezzinbi, A (2016) Optimization of medium composition for in vitro shoot proliferation and growth of date palm cv. Mejhoul. 3 Biotech 6:111. doi: 10.1007/s13205-0160430-x. 

by immature inflorescences

Mazri, MA; Ilham, B; Meziani, R; Mokhless, B; Souad, N (2017) Somatic embryogenesis from bud and leaf explants of date palm (Phoenix dactylifera L.) cv. Najda. 3 Biotech 7, 58. Morocco.

Malhat, MMH; El-Wakeel, H; Abd El-Hamid, A; Khalil, SM; Mona M. Hassan (2019) Direct embryogenesis and indirect organogenesis of date palm (Phoenix dactylifera $L$.) cv. Sewi using immature inflorescences. AUJAS, Ain Shams Univ., Cairo, Egypt, Special Issue 27, 737-747.

Mohan Jain S; Al-Khayri, JM; Johnson, DV (2011) Date Palm Biotechnology. Book. Springer.

Murashige, T; Skoog, FA (1962) Revised medium for rapid growth and bioassays with tobacco tissue cultures. Physiol Plant 15, 473-97.

Mushtaque, AJ; Abul-soad, AA; Solangi, N; Markhand, GS (2015) Establishment of an Efficient Protocol for Micropropagation of Some Pakistani Cultivars of Date Palm (Phoenix dactylifera L.) using novel inflorescence explants. Pak J Bot 47, 19211927.

Pottino, BG (1981) Methods in plant tissue culture. Dept. of Hort. Agric. College, Maryland Univ. College Park, Maryland, USA., pp. 8-29.

Rao, KS (1996) Embryogenesis in flowering plants: recent approaches and prospects. Biosci 21, 827841.

Reidy, Bo; Haase, A; Luch, A; Dawson, KA; Lynch, I (2013) Mechanisms of silver nanoparticle release, transformation and toxicity: a critical review of current knowledge and recommendations for future studies and applications. Materials (Basel) 6, 22952350.

Richards, RME; Odelola, HA; Anderson, B (1984) Effect of silver on whole cells and spheroplasts of a silver resistant Pseudomonas aeruginosa. Microbios 39, 151-157.
Rostami, AA; Shahsavar, A (2009) Nano silver particles eliminate contamination of olive : Mission explants. Asian J. of Plant Science pp 1682- 3974.

Russell, AD; Hugo, WB (1994) Antimicrobial activity and action of silver. Prog Med Chem 31, 351-370.

Shaheen, MA (1990) Propagation of date palm through tissue culture: A review and an interpretation. Ann Agric Sci 35, 895-909.

Sidky, RA (2014) The Effect of Picloram and Thidiazuron Concentrations on ProliferationSomatic Embryos from Immature Inflorescence of Date palm. Assiut J Agric Sci 45, 58-67.

Snedecor, GW; Cochran, WG (1982) Statistical Methods, 8th Ed. lowa State Univ. Press, Ames, lowa, USA.

Taha, HS; Hassan, MM; El-Bahr, MK (2007) Micropropagation of some Egyptian date palm dry cultivars, 1- Maturation of somatic embryos. Arab J Biotech 10, 333-340.

Tissert, B (1984) Propagation of date palm by shoot tip cultures. Hort Sci 19, 230-231.

Wang, S; Tang, L; Chen, F (2001) "In vitro flowering of bitter melon." Plant Cell Reports 20, 393-397.

Williams, RO; Yang, WJ; Peters, I (2005) Inhaled nanoparticles- A current review. Int $J$ of Pharmaceutics 356, 239-247.

Zaho, L; Peralta-Videa, JR; Cyren Rico, M (2014) $\mathrm{CeO} 2$ and $\mathrm{ZnO}$ nanoparticles change the nutritional qualities of cucumber (Cucumis Sativus L.) supporting information. Univ. of Texas. USA.

Zaid, A; Al Kaabi, HH; El-Korchi, B (2006) Impact of lower concentration of growth regulators on the multiplication stage of date palm organogenesis. $3^{\text {rd }}$ Intl. Date palm Conf. Abu Dhabi, UAE. 


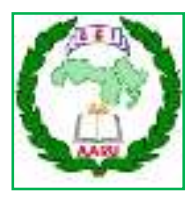

مجلة اتحاد الجامعات العربية للعلوم الزراعية، جامعة عين شمس، القاهرة، مصر

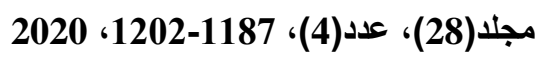

1202

Website: http://ajs.journals.ekb.eg

تأثير جسيمات النانو على الأكثار المعملي لنخيل البلح صنف البارحي بواسطة النورات الزهرية الغير ناضجة

[85]

فريد محمد رحيم1" - حسن الوكيل2 - أحمد عبد الحميد2 - أيمان عبد المنعم عبد الحميد1

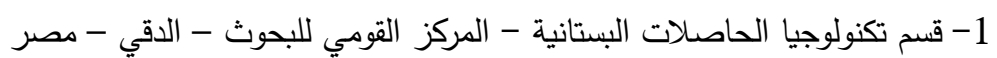

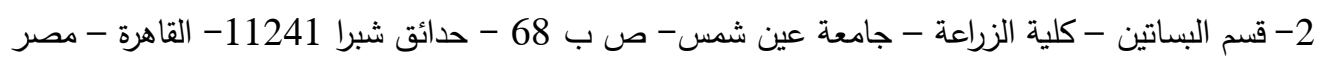

*Corresponding author: fm.rahim@nrc.sci.eg

Received 29 August, 2020

Accepted 1 November, 2020

التضاعف: سجلت أعلى عدد للأفرع الناتجة / منفصل

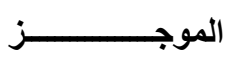

مع بيئة MS مضافا لها جسيمات الحديد النانوميترية بتركيز 20.8 ملجم/لتر ومع أضافة أيضا جسيات النسيمات

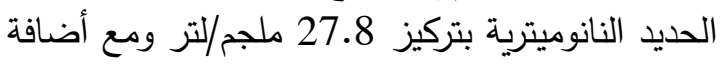
جسيمات الزنك النانوميترية بتركيز 4.3 ملجم/لتركيز الى الى التئ

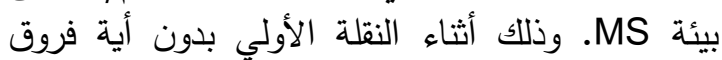

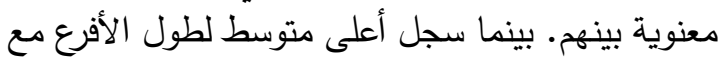

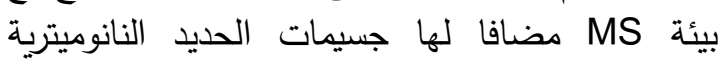

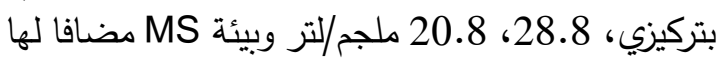

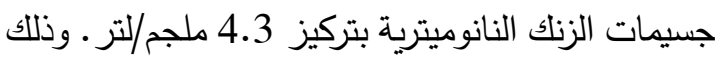

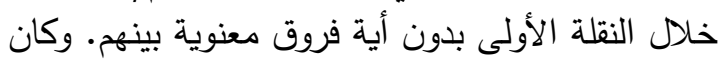

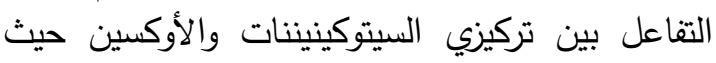

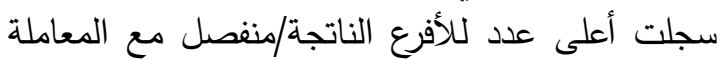

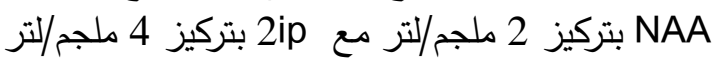

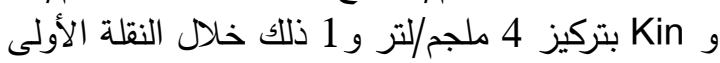

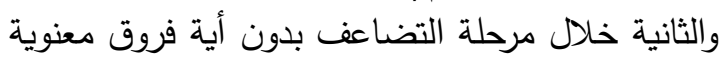

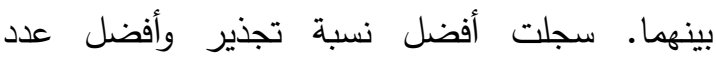
جذور/نبات مع بيئة MS مضافا لها NAA بتركية 0.5 ملجم/لتر بينما سجلت أعلى نسبة بقاء للنباتات خلات خلال

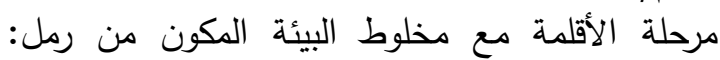

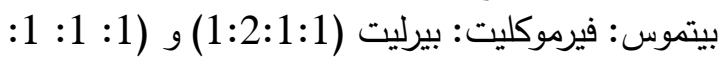
2) على التوالي.

فى دراسة لتأثير جسيمات الفضة والشيتوزان النانوميترية فى التعقيم وكذلك جزيئات الحديد والزنكاتك

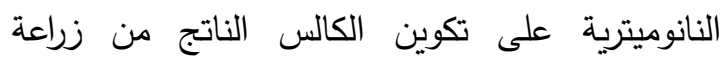
الأغاريض الزهرية غير الناضجة فئرئ مرحلة التأسيس لنخيل البلح صنف البارحي سواء التي تم غمس الأجزاء

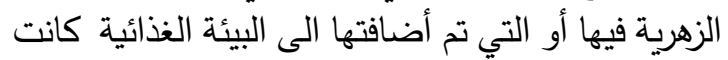

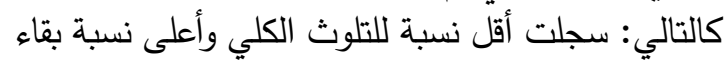
للمنفصلات مع المعاملة جسيمات الفضة النانية النوميترية بتركيز 200 ملجم/لتر ، والمعاملة بجسيمات الشيتوزان النانوميترية بتركيزي 150 و 200 ملجم/لتركيز ـ كذللك

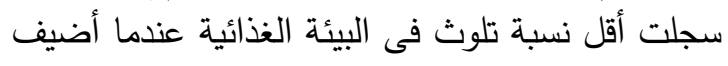

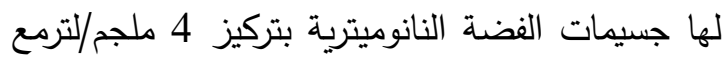

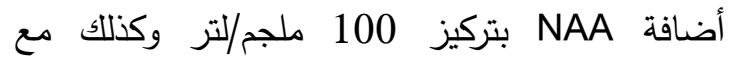

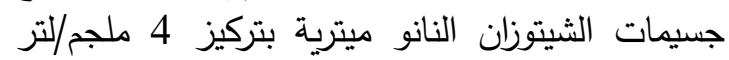

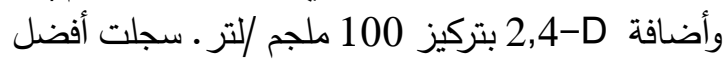
MS نسبة لتكوين الكالس وحجم الكالس الناتج مع بيئة

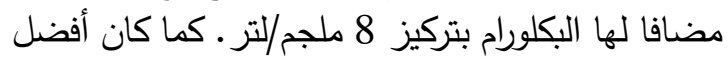

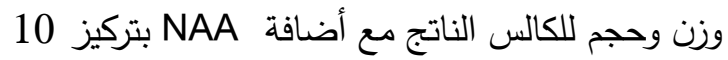
ملجم/لتر و Kin, 2ip بتركيزي 6 ملجم/لتر • في مرحلة 